\title{
Measurement of Temperament in Infancy
}

\author{
Mary Klevjord Rothbart
}

Unversity of Oregon

\begin{abstract}
Rothbaft, Many Ktevjofo Measurement of Temperament in Infancy Chud Development, 1981, 52, 569-578 Development of a caretaker-report instrument of the assessment of infant temperament is described, and longitudinal findings are reported Temperament dimensions were selected for investugation from the work of Thomas, Chess et al, Escalona, Diamond, and others Conceptual analysis of scale definitions was carned out to eliminate conceptual overlap of scales, and item analysis was performed for 463 Infant Behavior Questionnaires filled out for 3-, 6-, 9-, and 12-month-old subjects Scales with adequate psychometnc and conceptual properties were developed for the following dimensions activity level, soothability, fear, distress to limitations, smiling and laughter, and duration of orienting In longitudinal analyses, activity level and smilng and laughter scales revealed stability from 3 through 12 months, duration of onenting and soothability showed less general stability, and fear and distress to limitations showed stability only beyond the age of 6 months
\end{abstract}

Temperament as a psychobıological concept has been used in connection with the study of individual differences in other animal species (Diamond 1957), research on behavior genetics (Goldsmith \& Gottesman 1981), and the study of individual differences among human infants (Thomas \& Chess 1977) Since the concept of temperament provides an integrative approach to the study of the development of individual differences (Rothbart \& Derryberry, in press-a) and may eventually allow us to trace the relation between children's early characteristics and their social and cognitive development, the task of developing adequate measures for temperament is an important one

Although psychologists, pediatricians, and parents have been to some extent aware of temperamental differences among infants, only recently have researchers attempted to develop techniques for assessing temperamental characteristics of infants beyond the neonatal period (Bates, Freeland, \& Lounsbury 1979, Carey 1970, Carey \& McDevitt 1978, Persson-Blennow \& McNell 1979, Scarr \& Salapatek 1970, Thomas, Chess, Brch, Hertzig, \& Korn 1963, Torgersen \& Kringlen 1978, Pederson, Anderson, \& Cain, Note 1) In this paper, temperament will be defined as individual differences in reactivity and self-regulation Temperament is assumed to have a constitutional basis, with "constitutional" defined as the relatively enduring biological makeup of the individual, influenced over time by the interaction of heredity, life experience, and maturation (Rothbart \& Derryberry, in press-b)

All the studies listed above have used parent report to assess temperamental characteristics of the child, either via parent interview, $Q$ sort, or questionnare Parent reports have the advantage of utulizing the parent's extensive observations of the child over a wide variety of home situations in assessment of children's temperamental characteristics To the extent that parent report instruments overcome possible response biases (described by Bates [in press]), they provide a characterization of the infant's typical temperament behavior as seen in the home

We have cautioned elsewhere, however, that parent report measures do not provide an assessment of infant temperament that is independent of the child's current environment, rather, they measure the infant's behavior as seen in the home (Rothbart \& Derryberry, in press-a) Behavior in the home reflects the result of the interaction between patterns of social stimulation in the home and the child's own temperamental patterns of reactivity and

This research was partially supported by grant 5 R01 MH 26674-04 from the National Institute of Public Health. I wish to thank the following persons for their contributions to the research Lita Furby, Susanna Kelly, and Joan Hamiton Portions of this study were previously reported at the meetings of the Society for Research in Child Development, New Orleans, March 1977 Requests for repnnts, copies of the Infant Behavior Questionnaure and sconng procedures should be sent to Mary K Rothbart, Department of Psychology, University of Oregon, Eugene, Oregon 97403

(Chald Development, 1981, 52, 569-578 (C) 1981 by the Society for Research in Child Development, Inc $0009-3920 / 81 / 5202-0005 \$ 0100]$ 
self-regulation Parent report measures of temperament may thus be seen as assessing temperament as it is demonstrated within the infant-caregiver system of interaction Viewed in this way, parent-reported temperament allows us to make group and developmental comparisons, for example, examining developmental sex differences in temperament in the home or characterizing the behavior of Down's syndrome infants in companson with matched normal infants (Hanson 1979), but we must realize in making these comparisons that our temperament measure is not independent of the children's home environment

The first attempt at large-scale assessment of infant temperament via parent report was the work of Thomas, Chess, and therr colleagues (Thomas \& Chess 1977, Thomas, Chess, \& Birch 1968, Thomas et al 1963) Parents of 141 children from 85 New York famlles were interviewed during the first 2 years of their infants' lives After a content analysis of their first 22 intervews, Thomas et al (1963) chose the following temperament charactenstics for further analysis activity level, rhythmicity, approach, adaptability, threshold, intensity, attention span, distractibility, and persistence These dimensions were chosen because they were found to be scorable for all protocols and because they allowed a sufficiently wide distribution of scores for further study Two-hour interviews were scored on three-point scales for all behavior items corresponding to given temperament variables Preponderance scores were then determined by tallying frequencies of high, medium, and low responses for each child

The Thomas et al studies have been highly influential in the study of infant temperament, although there are some problems in interpreting their results First, it is impossible to determine the extent of homogeneity within any given behavior scale for example, if activity is mentioned rarely by the mother, a high score on activity could result from activity only during the feeding situation Temperament scales are also constramed by the three-point scale used in protocol scoring Second, the subjects ranged in age from 2 months to 6 months at the time of the first interview, with subsequent interviews held at 3-month periods Some of the subjects were thus considerably older than other subjects during all phases of the study, and differences related to age may have confounded findings of actual individual differences among the children $F_{1-}$ nally, the New York sample was highly re- stricted with respect to SES and ethnic group, and $47 \%$ of the families contributed more than one subject to the project

Since the Thomas et al studies, there have been several attempts to devise parent report instruments based on the New York temperament interviews Scarr and Salapatek (1970) chose items based on examples from Thomas et al's 1963 book, to which mothers were asked to respond "mostly true" or "mostly false" Children in the study ranged in age from 2 months to 24 months Item analyses were carried out for 70 mothers' responses to these items, but the investigators reported that internal consistency of the scales "was found to be rather low" The Scarr-Salapatek questionnaire has not been used in subsequent studies of infant temperament

A questionnaire devised by Carey (1970), however, has been used in the Rochester infancy study (Bakow, Sameroff, Kelly, \& Zax, Note 2) and extensively in other temperament research (reviewed by Thomas \& Chess [1977]) Carey originally developed a 70-1tem questionnaire primarily as a clinical screening device for pediatricians The questions were also based on the Thomas et al work, and nune scales measured the characteristics defined in the New York study No item analysis was carried out for Carey's first instrument More recently, however, Carey and McDevitt (1978) have revised the nine scales, using 203 4-8-monthold infants for a standardization population Internal consistency of this revised scale ranges from 49 to 71 (statistic unspecified), with a median of 57

Pederson, Anderson, and Cain (Note 1) have developed a $Q$ sort measure for assessing parents' perceptions of Thomas et al 's (1963, 1968) nine categories of temperament They report corrected spht-half reliabilities for the dimensions of activity, rhythmicity, adaptability, approach, and positive mood ranging from 54 to 69 , with a median of 60 They had less success measurng the dimensions of threshold, persistence, distractibility, and intensity, with corrected split-half correlations ranging from 31 to 48 , with a median of $40 \mathrm{~A}$ questionnaire in Swedish (Persson-Blennow \& McNeil 1979) and an interview schedule in Norwegıan (Torgersen \& Knnglen 1978) based on the Thomas et al $(1963,1968)$ categories have also been developed

Bates et al (1979) have developed a caretaker-rating instrument, the Infant Characteristics Questionnaire, consisting of 24 items 
scored on seven-point scales Responses of 322 mothers of 4-6-month-old infants were factor analyzed, yielding four factors labeled by Bates et al as (1) fussy/difficult, (2) unadaptable, (3) dull, and (4) unpredictable Internal consistency estimates for the factor scales with a cross-validational sample of $N=196$ ranged from 39 to 79 , with a median coefficient $\alpha$ of 63

\section{Infant Temperament Dimensions}

The purpose of the present project in developing a parent report instrument of infant temperament was to develop a psychometrically adequate instrument as reflected by high internal reliability that would measure not only the Thomas, Chess et al $(1963,1968)$ dimensions, but would tap other aspects of reactivity and self-regulation that had been identıfied as involving individual differences with a possible constitutional basis In addition, we wished to identufy dimensions of temperament that were conceptually independent, that is, involving no overlap among operational definitrons Both the Thomas et al work and the work by Carey (1970, Carey \& McDevitt 1978) had involved such overlap, and it was hoped that, by developing conceptually distinct temperament dimensions, we could adequately explore correlations between dimensions without inflating them by using simular items on scales with different names It was also hoped that we could study both developmental contunuty and change in children's patterns of reactivity and self-regulation as observed over time in the home

Choice of inital temperament dimensions for the present research was therefore based upon the work of Thomas et al $(1963,1968)$ but was influenced by other research and theory as well, notably the work of Escalona (1968) and Shrley (1933), studies of temperament and behavior genetics in animals and humans (reviewed by Dramond [1957]), and longitudinal studies of personality in human subjects On the basis of this review, 11 temperament dimensions were selected for initial investigation Four of the variables may be seen as tapping general characteristics of response as assessed across differing sensory receptors and response channels, these include threshold, intensity, and adaptability (soothability) of response, and rhythmicity Seven variables involve activation of more restricted responses activity level, fear, distress to limitations, overall negative emotionality, smilng and laughter, duration of orienting, and distractiblity The short literature reviews given with each variable below are not inclusive, studies are cited to point up the importance of the dimension to temperament research, more inclusive reviews may be found in Rothbart and Derryberry (in press-a)

Activty level -Level of gross motor activity has probably been the most widely studied temperamental characteristic in young children (e g, Escalona 1968, Fries \& Woolf 1953, Ruchards \& Newberry 1938, Schaffer 1966, and Thomas et al 1963), and anumal behavior genetics work (Fuller \& Thompson 1978) as well as human twin study research have suggested that activity level may be heritable (Matheny, Dolan, \& Wilson 1976, Scarr 1966, Willerman 1973, Willerman \& Plomm 1973) Buss and Plomin (1975) reviewed longitudinal studies on activity level, concluding that activity level shows stability as a personality dimension only after the period of infancy In the early months, however, Burns, Barten, and Bridger (1969) have found consistency of activity between infants of 1 and 4 months

Fear (distress and extended latency to approach intense or novel stimuli) -An approach scale (defined as acceptance or rejection of new objects or persons) was uncluded in the Thomas et al study (1963), and reaction to intense or novel stimulı appears to be a highly promising dimension for the study of temperament in children Infants do show fear responses (Bronson 1968, Scarr \& Salapatek 1970), and animal studies have indicated the existence of inherited individual differences in fearfulness in rats, dogs, and chimpanzees (Fuller \& Thompson 1978, Hall 1951, Yerkes \& Yerkes 1936) High heritability coefficients have also been found on anxiety ratings for both child and adult twin pairs (Gottesman 1963, Scarr 1966)

Distress to limtations - This variable has been chrefly studied in connection with persistence and goal orientation, since individual differences in infants' reactions to frustrating conditions may be easily observed Kramer and Rosenblum (1970), for example, studied the reactions of 1-year-olds to the placing of a glass barrier between the child and an attractive toy Three kinds of response were observed some infants were persistent and managed to reach the toy, some shifted their attention to another environmental focus without reaching the toy, a third group became distressed and quickly 
lost interest in the toy Evidence for heritabulity of persistence of goal orientation has been put forward by Torgersen and Kringlen (1978) and Goldsmith and Gottesman (1981), and Wilson, Brown, and Matheny (1971) have reported that "temper frequency" formed the core of a cluster of distress items in child behavior as reported by maternal interviews from 6 to 36 months Aggressiveness is a trat for which animal crossbreeding has been successful (Hall \& Klein 1942), but we do not know the precise relation between an aggressive response and a distress response to frustration In addition to the distress scales listed above, an attempt was made to assess a general dimension of negative emotionality

Threshold, intensty, and adaptabulty (soothability) of response - The Thomas et al (1963) study included scales for intensity, threshold, adaptability, and mood $A$ study by Freedman (1971) using the Brazelton assessment of neonatal temperament compared 24 Chinese-American newborns with 24 EuropeanAmencan newborns, finding that the EuropeanAmencan infants reached a peak of excitement earher in the assessment penod, wavernng between contentment and upset, whle the Chrnese-Amencans scored on the calmer and steadier side of these items, were more easly consoled, and were more likely to soothe themselves Birns et al (1969) found stability on ratings of irritability, sensitivity, and soothability over the first 4 months In the Thomas et al (1968) study, intensity of individual response showed relatuvely high stability over time and showed consistent positive correlations with other temperament scales However, many of these correlations may be artifactual, since the same mother's statement could be coded for any number of scales For example, intensity of response, threshold, and mood were often scored from the same statements

Smiling and laughter - Smiling and laughter have been identified as indicators of arousal under safe conditions (Rothbart 1973, Sroufe \& Waters 1976) and deserve more thorough exploration as indications of emotional reactivity than has been the case Buss and Plomm (1975), for example, have argued that posttive emotons do not reflect constitutionally based emotionality Freedman (1971), however, presents evidence that paurs of identical twins are more alke than pairs of fraternal twins in smiling durnng the first year Wilson, Brown, and Matheny (1971) also report that smiling constitutes part of a sociability cluster extracted from maternal reports of child behavior from 6 months through 72 months of age

Rhythmucty - Rhythmicity of sleep and hunger cycles and bowel movements was measured by Thomas et al and described as a characteristic of the "easy child"

Duration of orienting and distractibulity Thomas et al (1963, 1968) measured both attention span and distractibility in infants and young chuldren, thereby pointing up the possibility of important individual differences in the development of attention Attentional variables are of interest in that several researchers using different age groups and quite different procedures (Cohen 1975, McCall \& Kagan 1970, McCall \& Melson 1969, Paden 1975, Self 1975) have reported that infants differ in their rate of habituation and, hence, duration of orienting over trials Wilson, Brown, and Matheny (1971) have reported attention span to be negatively related to a cluster including temper frequency and intensity from 6 through 18 months of age

In the present study, preparation of the scales involved both conceptual and item analysis After these analyses, six scales were developed with adequate conceptual and psychometric characteristics activity level, smiling and laughter (originally labeled positive emotonality), fear, distress to limitations (onglnally labeled anger/frustration), soothability, and duration of orienting (originally labeled persistence)

\section{Method}

Initual items for the Infant Behavior Questionnaire were developed from the work of Shrrley (1933), Thomas et al (1963), and others, as well as from intensive interviews with 26 parents of 3-, 6-, 9-, and 12-month-old infants Items were selected to assess one of 11 different dimensions of temperament listed above In order to avold the real problems often associated with parent report (Weick 1968, Yarrow 1963), we wished to avoid asking parents either to make global judgments of their child's behavior or to attempt to recollect occasions of child behavior from the distant past We did not wish to ask parents to make comparative judgments about ther infants-for example, "my child is extremely active"since information about the behavior of other infants might not be avalable to them Items in the instrument were therefore carefully worded to refer to specific behaviors, and care- 
takers were asked to respond on the basis of the infant's specific behavior durir'z the past week Data from the experimental literature (Hasher \& Zacks 1979) suggest that (2) frequency judgments of even nonattended nems tend to be remembered with some accuracy, (b) frequency judgments tend to be made independently from recency or duration information, and $(c)$ giving explicit instructions for attending and frequency of occurrence of items does not greatly improve performance in memory for frequency An example of the questionnarre items used in the item analysis is given below The responses were coded on a scale from 1 to $61=$ never, $2=$ once or twice, $3=$ less than half the tume, $4=$ about half the time, $5=$ more than half the time, $6=$ almost always, $\mathrm{X}=$ does not apply

Durnng the past week, when being undressed, how often did your baby

\begin{tabular}{ccccccc}
\multicolumn{7}{c}{ Wave his/her arms and kack? } \\
$\begin{array}{c}1 \\
\text { Cry? }\end{array}$ & 3 & 4 & 5 & 6 & X \\
$\begin{array}{r}1 \\
\text { Smle or laugh? }\end{array}$ & 3 & 4 & 5 & 6 & X \\
1 & 2 & 3 & 4 & 5 & 6 & X
\end{tabular}

We have recently modified the response optons, making them more symmetrical and more nearly an interval scale The improved response options are as follows $1=$ never, $2=$ very rarely, $3=$ less than half the tıme, $4=$ about half the time, $5=$ more than half the time, $6=$ almost always, $7=$ always, $X=$ does not apply

A response option for indicating that an item "does not apply" was included because some of the specific situations described in the questionnaire may not have occurred during the previous week for a particular infant, for example, the infant may not have been given a new food or liquid or left with a babysitter Although it has not been possible to assess response bias for a given subject (since, e $g$, the tendency to use only the high end of the scale may be an altogether valid indicator of a partıcular child's behavior), our emphasis on caretakers' estumating the relative frequency of concrete behaviors durng the past week tends to minimize the possibility of bias In addition, the inclusion of a number of reverse items minlmizes effects of response bias, with scores for these items reversed when computing the relevant scale score For example, a reverse item for the activity scale is "Durmg sleep, how often did your baby sleep in one position onlyp" A score of 6 on this item reflects low activity, and is translated into a $I$ when activity scores are computed

Two kinds of analyses have been performed on these scales conceptual and item analyses The conceptual analysis has unvolved (a) development of precise operational definitions of each dimension of temperament and (b) subsequent elimination of scales that conceptually overlap with each other Two of the original 11 scales were discarded because of unavordable conceptual overlap with other temperament scales negative emotionality showed overlap with both the distress to limitations and fear scales, and we were not able to formulate a mutually exclusive operational definition of distractibilitv Definitions of temperament dimensions remaining after completion of conceptual and item analyses are listed in table 1 Several of the temperament dimensions have also been relabeled in an attempt to reflect only information conveyed in the operational definitions and avoid insofar as possible value judgments inherent in scale names, for example, names like "persistence" and "positive emotionality"

TABLE 1

Temperament Dimension Definitions

\begin{tabular}{ll}
\hline Dimension & $\begin{array}{l}\text { Child's gross motor activity, including movement of arms and legs, squirming, and } \\
\text { locomotor activity } \\
\text { Activity level }\end{array}$ \\
$\begin{array}{l}\text { Smiling or laughter from the child in any situation } \\
\text { The child's distress and/or extended latency to approach an intense or novel stimulus } \\
\text { Fear } \\
\text { Distress to limitations } \\
\text { Child's fussing, crying, or showing distress while }(a) \text { waiting for food, }(b) \text { refusing a } \\
\text { food, }(c) \text { being in a confining place or position, }(d) \text { being dressed or undressed } \\
(e) \text { being prevented access to an object toward which the child is directing her/his } \\
\text { attention } \\
\text { Child's reduction of fussing, crying, or distress when soothing techniques are used by } \\
\text { the caretaker or child } \\
\text { The child's vocalization, looking at, and/or interaction with a single object for extended } \\
\text { periods of time when there has been no sudden change in stimulation }\end{array}$ \\
Duration of orienting
\end{tabular}




\section{Item Analysts}

Subjects - Four hundred and suxty-three Infant Behavior Questionnaires were filled out by parents of 3-, 6-, 9-, and 12-month-old infants There were 94 3-month-old infants (mean age 142 weeks, range 12-18 weeks, 51 girls and 43 boys), 115 6-month-old infants (mean age 274 weeks, range 24-32 weeks, 55 gurls and 60 boys), 1499 -month-old infants (mean age $40 \mathrm{I}$ weeks, range $38-46$ weeks, 72 girls and 77 boys), and 106 12-month-old infants (mean age 529 weeks, range 51-57 weeks, 59 girls and 77 boys) Mothers responded to a letter requesting participation in the study, and letters were sent to parents of newborns listed in burth announcements of the local newspaper Fifty-nine percent of parents to whom questionnaires were maled actually participated in the project Subjects were socioeconomically heterogeneous, but racially homogeneous (Caucasian), representing the EugeneSpringfield, Oregon, population

The onginal sample for the item-analysis consisted of 933 -month-olds, 63 6-month-olds, and 59 9-month-olds If parents were willing to fill out a questionnare at subsequent 3month intervals for theur child, they were encouraged to do so The final item refinement sample thus included some children who were rated more than once $W e$ felt that nonindependence of the sample would not interfere with determination of item-scale charactenstics for different ages On the other hand, having longitudinal data on some of the subjects would allow initial assessment of stability of temperament scores

Item analyses were performed for all scales at all ages, retanning only those items correlating 20 or better with scales scores for a given age Since the response format requires that respo idents be able to indicate which situations to not apply, that is, those situations which ruay not have occurred for a particular infari, each scale score is computed by taking the average item score, omitting those indicated as "does not apply"

Three scales were elimmated because of unsatisfactory item characteristics and internal reliability threshold, rhythmicity, and intensity We also found that only the soothability items of the onginal adaptability scale had satisfactory interitem-correlations They were therefore extracted to form a soothability scale A summary of the ranges and means of itemscale correlations for temperament scales in the refined instrument is given in table 2 , and internal rehabilities of the scales based on coefficient $\alpha$ are given in table 3

\section{Household Reliability}

A subsample of 22 mothers filled out the questionnaire along with a second adult in the household (father or babysitter) who spent tume caring for the infant Although mothers were asked not to discuss the items with the other individual filling out the questionnaire, we did not have direct control over such discussion, questionnaures were all mailed to the parents' home Reliability product-moment correlations for the 22 matched pairs of questionnaires were smiling and laughter, $r=45$, duration of orienting, $r=46$, soothability, $r=$ 54 , fear, $r=66$, distress to limitations, $r=$ 60 , actuvity level, $r=69$ All correlations were significant at $p<05$ levels (one-talled tests)

\section{Stabultty}

Of the onginal sample, 36 of the 3-monthold infants' mothers filled out the questionnaire again when their infants were 6,9 , and 12

TABLE 2

Ranges and Means of Item-Scale Correlations, Inpant Behavor Questionnaire

\begin{tabular}{lcccc}
\hline & 3 Months & 6 Months & 9 Months & 12 Months \\
\hline Activity level & $34-62$ & $31-63$ & $30-65$ & $27-75$ \\
Smling and laughter & $(45)$ & $(47)$ & $(51)$ & $(52)$ \\
Fear & $40-75$ & $29-62$ & $28-64$ & $27-74$ \\
Distress to limitations & $(57)$ & $(49)$ & $(46)$ & $(51)$ \\
Soothabihty & $35-65$ & $22-67$ & $22-79$ & $22-76$ \\
Duration of orienting & $(50)$ & $(43)$ & $(49)$ & $(53)$ \\
& $(49)$ & $31-65$ & $35-58$ & $26-66$ \\
& $(52-69$ & $(46)$ & $(41)$ & $(44)$ \\
& $39-73$ & $(46)$ & $35-57$ & $35-68$ \\
& $(57)$ & $(58)$ & $(44)$ & $(52)$ \\
& & & $(61)$ & $(60)$ \\
\hline
\end{tabular}

Notx -Means are in parentheses 
months of age, 34 infants of the 6-month sample were retested at 9 and 12 months, and 36 infants of the 9-month sample were retested at 12 months Age to age productmoment correlations were performed for these three longitudinal cohorts and are described in table 4 For both the scales of activity level and smilng and laughter, the correlations reveal considerable stability, and stability is found for most cohorts and age comparisons for the scales of duration of orienting and soothability For scales measuring fear and distress to lim1tations, 3-month scores are not predictive of later scores, with stability found only in predictions from 6 months

\section{Intercorrelations among Scale Scores}

Temperament scales were designed to avord conceptual overlap, allowing us to examine empincal intercorrelations among temperament scale scores Intercorrelations among scale values for 6 - and 12 -month infants from the item-refinement sample are reported in table 5 Positive correlations are found at both ages between activity level and distress to limltations, $r=28$ and 33 , and between distress

TABLE 3

Coepficient as for Temperament Scales, INFANT BEHAVIOR QUESTIONNATRE

\begin{tabular}{lcccc}
\hline & $\begin{array}{c}3 \\
\text { Months }\end{array}$ & $\begin{array}{c}6 \\
\text { Months }\end{array}$ & $\begin{array}{c}9 \\
\text { Months }\end{array}$ & $\begin{array}{c}12 \\
\text { Months }\end{array}$ \\
\hline Activity level (17 items) & 73 & 77 & 81 & 84 \\
Smiling and laughter (15 items) & 85 & 77 & 73 & 80 \\
Fear (16 items) & 80 & 81 & 84 & 81 \\
Distress to limitations (20 items) & 84 & 80 & 75 & 78 \\
Soothability (11 items) & 84 & 75 & 73 & 82 \\
Duration of onienting (8 items) & 72 & 67 & 75 & 72 \\
\hline
\end{tabular}

TABLE 4

Stability Correlations gor Temperament Scales, INfant Behavior Questionnaire

\begin{tabular}{|c|c|c|c|c|c|c|}
\hline & $\begin{array}{c}3-6 \\
\text { Months }\end{array}$ & $\begin{array}{c}3-9 \\
\text { Months }\end{array}$ & $\begin{array}{c}\text { 3-12 } \\
\text { Months }\end{array}$ & $\begin{array}{c}6-9 \\
\text { Months }\end{array}$ & $\begin{array}{c}G-12 \\
\text { Months }\end{array}$ & $\begin{array}{c}\text { 9-12 } \\
\text { Months }\end{array}$ \\
\hline $\begin{array}{l}\text { Activity level } \\
\text { C1 } \\
\text { C2 } \\
\text { C3 }\end{array}$ & $57^{* * *}$ & $60^{* * *}$ & $48^{* * *}$ & $\begin{array}{l}49^{* * *} \\
57^{* * *}\end{array}$ & $\begin{array}{l}60^{* * *} \\
60^{* * *}\end{array}$ & $\begin{array}{l}60^{* * *} \\
67^{* * *} \\
78^{* * *}\end{array}$ \\
\hline $\begin{array}{l}\text { Smling and laughter } \\
\mathrm{C} 1 \\
\mathrm{C} 2 \\
\mathrm{C} 3\end{array}$ & $60^{* * *}$ & $63^{* * *}$ & $57^{* * *}$ & $\begin{array}{l}81^{* * *} \\
73^{* * *}\end{array}$ & $\begin{array}{l}78^{* * *} \\
66^{* * *}\end{array}$ & $\begin{array}{l}80^{* * *} \\
78^{* * *} \\
58^{* * *}\end{array}$ \\
\hline $\begin{array}{l}\text { Duration of orienting } \\
\mathrm{C} 1 \\
\mathrm{C} 2 \\
\mathrm{C} 3\end{array}$ & $36^{*}$ & $35^{*}$ & 11 & $\begin{array}{l}71^{* * *} \\
53^{* *}\end{array}$ & $\begin{array}{l}47^{* * *} \\
21\end{array}$ & $\begin{array}{l}70^{* * *} \\
55^{* * *} \\
68^{* * *}\end{array}$ \\
\hline $\begin{array}{l}\text { Soothability } \\
\text { C1 } \\
\text { C2 } \\
\text { C3 }\end{array}$ & 30 & $37^{*}$ & $41^{*}$ & $\begin{array}{l}49^{* *} \\
51^{* *}\end{array}$ & $\begin{array}{l}33^{*} \\
45^{* *}\end{array}$ & $\begin{array}{l}56^{* * *} \\
-45^{* *} \\
-14\end{array}$ \\
\hline $\begin{array}{r}\text { Fear } \\
\mathrm{Cl} \\
\mathrm{C} 2 \\
\mathrm{C} 3\end{array}$ & 23 & 09 & 06 & $\begin{array}{l}59^{* * *} \\
33\end{array}$ & $\begin{array}{l}39^{*} \\
35^{*}\end{array}$ & $\begin{array}{l}69^{* * *} \\
44^{* *} \\
69^{* * *}\end{array}$ \\
\hline $\begin{array}{l}\text { Distress to limitations } \\
\mathrm{Cl} \\
\mathrm{C} 2 \\
\mathrm{C} 3\end{array}$ & 27 & 20 & 25 & $\begin{array}{l}48^{* * *} \\
72^{* * *}\end{array}$ & $\begin{array}{l}63^{* * *} \\
60^{* * *}\end{array}$ & $\begin{array}{l}58^{* * *} \\
74^{* * *} \\
63^{* * *}\end{array}$ \\
\hline
\end{tabular}

Note - For cohort 1(C1), $N=36$, for cohort $2(\mathrm{C} 2), N=34$, for cohort $3(\mathrm{C} 3), N=36$

$* p<05$

$* * p<01$

$* * 0<001$, all two-taled tests 
TABLE 5

SCALE INTERCorrelations, INFANT Behavior QUEstronNaire

\begin{tabular}{|c|c|c|c|c|c|c|}
\hline & $\begin{array}{c}\text { Activity } \\
\text { Level }\end{array}$ & Fear & $\begin{array}{c}\text { Distress } \\
\text { to } \\
\text { Lamitations }\end{array}$ & $\begin{array}{l}\text { Smiling } \\
\text { and } \\
\text { Laughter }\end{array}$ & $\begin{array}{l}\text { Sooth- } \\
\text { ability }\end{array}$ & $\begin{array}{c}\text { Duration } \\
\text { of } \\
\text { Orienting }\end{array}$ \\
\hline $\begin{array}{l}\text { Activity level } \\
\text { Fear } \\
\text { Distress to limitations } \\
\text { Smling and laughter } \\
\text { Soothability } \\
\text { Duration of orienting }\end{array}$ & $\begin{array}{l}02 \\
33^{* *} \\
00 \\
-02 \\
05\end{array}$ & $\begin{array}{l}07 \\
29^{* *} \\
-34^{*} \\
00 \\
04\end{array}$ & $\begin{aligned} & 28^{* *} \\
& 36^{* *} \\
- & 30^{*} \\
- & 13 \\
- & 16\end{aligned}$ & $\begin{array}{l}11 \\
-\quad 22^{*} \\
-\quad 19 \\
17 \\
19\end{array}$ & $\begin{aligned} 03 \\
-01 \\
-\quad 12 \\
29 * * \\
19\end{aligned}$ & $\begin{array}{r}-01 \\
05 \\
-\quad 14 \\
19 \\
05\end{array}$ \\
\hline
\end{tabular}

NotE - 6-month correlations above diagonal $(N=93) \quad 12$-month correlations below diagonal $(N-106)$

$* p<05$

$* * p<01$, two-talled tests

to limitations and fear, $r=36$ and 29 Negarve correlations are found between smiling and laughter and fear, $r=-22$ and $-34 \mathrm{~A}$ positive correlation is found between smiling and laughter and soothability at 6 months, $r=29$, and $a$ negative correlation between smiling and laughter and distress to limitations at 12 months, $r=-30$

\section{Discussion}

The present research has developed internally reliable scales for the measurement of parent-reported activity level, smiling and laughter, fear, distress to limitations, soothability, and duration of onenting Although the scales were designed to avoud conceptual overlap, positive intercorrelations were nevertheless found between distress to limitations and fear, distress to limitations and activity level, and smiling and laughter and soothability Negative correlations were found between sming and laughter and fear and smilng and laughter and distress to limitations These intercorrelations indicate a positive relation between the two measures involving assessment of distress and a negative relation between smiling and laughter and the two distress measures As assessed in the home, there is thus some evidence of general mood differences among children, although the intercorrelations are not high The positive correlation between activity level and distress to limitations may refect a tendency for more active children to be more frustrated when their body movements are restrained These interpretations of intercorrelations are preliminary, since they will be further explored through home observation of infant temperament

There is evidence of some agreement among the IBQ responses of two adults who are reporting about the same infant This agree- ment occurs in spite of the fact that two adults who interact with the infant at different times may provide quite different elicitations of temperamental behavior in the infant, for example, in their encouragement of the child's smiling and laughter or in the effectiveness of their soothing techniques

The scales measuring activity level and smling and laughter and, to a lesser extent, duration of onenting and soothability show considerable stability from one age to another The scales measuring fear and distress to limitations do not show stability from 3 months, but this lack of stability might be predicted from individual differences in maturationally related changes in fear reactions (Emde, Note 3 ) and in development of an understanding of means-ends relations (Praget 1952) that would influence older infants' reactions to frustration

Measures such as the Infant Behavior Questionnaire, which reflect temperament as evidenced in an interacting system involving caregivers and siblings as well as constitutionally based characteristics of the child, may show stabilities that we would not find in a laboratory environment It is possible, for example, that parents develop styles of interacting with infants that are highly stimulating, moderately stimulating, or involving a minimum of stumulation These styles of parent-infant interaction may remain fairly stable over the early months of life, resulting in relatively stable patterns of child behavior in the home Alternatively, parents may maintain stability of infant temperament behavior by attempting to provide whatever level of stimulation is effective at a given age for producing a particular reaction in the child, for example, some parents may act to stımulate smiling and laughter or to produce body movement in their child 
The stability represented in these findings may of course also reflect response biases within a given parent The fact that the fear and distress to limitations scales do not show stabihty across all ages, however, and that these instabilities are theoretically predictable, suggests that the results are not the product of response sets alone Further validational study involving comparison of temperament scale scores with home and laboratory observation of infant temperament is presently being carried out in an attempt to investigate this question

\section{Reference Notes}

1 Pederson, F A, Anderson, B J, \& Caun, R L, Jr A methodology for assessing parental perception of infant temperament Paper presented at the Southeastem Conference on $\mathrm{Hu}$ man Development, 1976

2 Bakow, H, Sameroff, A, Kelly, P, \& Zax, $M$ Relation between newbom behavior and mother-child interaction at four months Paper presented at the meeting of the Society for Research in Child Development, Philadelphıa, March 1973

3 Emde, $\mathbf{R} \mathbf{N}$ Two developmental shifts in infant biobehavioral organization two months and seven-nine months In Qualhtative transitions in behavior dunng infancy Symposium presented at the meeting of the Society for Research in Child Development, New Orleans, 1977

\section{References}

Bates, J E The concept of difficult temperament Merrll-Palmer Quarterly, in press

Bates, J E, Freeland, C A, \& Lounsbury, M L Measure of infant difficultness Chald Development, 1979, 50, 794-803

Bırns, B, Barten, S, \& Bndger, W Individual differences in temperamental characteristics of infants Transactions of the New York Academy of Sctences, 1969, 31, 1071-1082

Bronson, G W The development of fear in man and other animals Child Development, 1968, $39,409-431$

Buss, A H, \& Plomin, R A temperament theory of personaluty New York Wiley, 1975

Carey, W B A simplified method for measuring infant temperament Joumal of Pediatncs, $1970,77,188-194$

Carey, W B, \& McDevitt, S C Revision of the infant temperament questionnaire Pediatrcs, $1978,61,735-739$

Cohen, L B Infant visual memory a backward look into the future In N P Ellis (Ed), Aberrant development in infancy New York Wiley, 1975

Diamond, S Personality and temperament New York Harper, 1957

Escalona, S K The roots of individuality normal pattems of development in infancy Chicago Aldine, 1968

Freedman, D G Genetic influences on development of behavior In G B A Stoelinga \& J J Ven der Werff Ten Bosch (Eds), Normal and abnormal development of behavior Le1den Leiden University Press, 1971

Fnes, M, \& Woolf, $\mathrm{P}$ Some hypotheses on the role of congenital activity type in personality development In R Eissler et al (Eds), The psychoanalytic study of the chrld Vol 8. New York International Universities Press, 1953

Fuller, J L, \& Thompson, W R Foundations of behavior genetrcs St Louls Mosby, 1978

Goldsmith, $\mathrm{H} \mathrm{H}$, \& Gottesman, I I Ongins of variation in behavioral style a longitudinal study of temperament in twins Chald Development, 1981, in press

Gottesman, I I Heritability of personality a demonstration Psychological Monographs, 1963, 77 (9, Whole No 572)

Hall, $C S$ The genetics of behavior In S S Stevens (Ed), Handbook of expenmental psychology New York Wiley, 1951

Hall, $C S, \&$ Klem, S J Individual differences in aggressiveness in rats Joumal of Comparative Psychology, 1942, 33, 371-383

Hanson, M J A longitudinal, descnptive study of the behaviors of Down's syndrome infants in an early intervention program Monograph of the Center on Human Development Eugene Unuversity of Oregon, 1979

Hasher, L, \& Zacks, R T Automatic and effortful processes in memory Joumal of Expertmental Psychology General, 1979, 108, 356388

Kramer, Y, \& Rosenblum, L A Responses to "frustration" in one-year-old infants Psychosomatic Medicine, 1970, 32, 243-247

Matheny, A P, Jr, Dolan, A B, \& Wilson, R S Twins within-pair similanty on Bayley's infant behavior record Journal of Genetic Psychology, 1976, 128, 263-270

McCall, $\mathbf{R}$, \& Kagan, $\mathbf{J}$ Individual differences in the infants' distribution of attention to stimulus discrepancy Developmental Psychology, $1970,2,90-98$

McCall, R, \& Melson, $W$ Attention in infants as a function of magnitude of discrepancy and habituation rate Psychonomic Scrence, 1969 , 17, 317-319 
Paden, L Y The effects of auditory stimulation (music) and interspersed stimulus procedures in visual attending behavior in infants In F D Horowitz (Ed ), Visual attention, auditory stimulation, and language discrimination in young infants Monographs of the Society for Research in Chtld Development, 1975, 39 (5-6, Senal No 158)

Persson-Blennow, I, \& McNetl, T F A questionnare for measurement of temperament in sixmonth old infants development and standard1zation Journal of Chuld Psychology and Psychratry, 1979, 20,1-13

P1aget, J The ongins of intelligence in children New York International Unuversities Press, 1952

Richards, T W, \& Newberry, $H$ Studies on fetal behavior, III Can performance on Gesell Test Items at six months postnatally be predicted on the basis of fetal activity? Chuld Development, 1938, 9, 79-86

Rothbart, M K Laughter in young children Psychological Bulletin, 1973, 80, 247-256

Rothbart, M K, \& Derryberry, D Development of individual differences in temperament In M E Lamb \& A L Brown (Eds), Advances in developmental psychology, Vol 1. Hillsdale, N J Erlbaum, in press (a)

Rothbart, $\mathbf{M} \mathbf{K}$, \& Derryberry, D Theoretical issues in temperament In $M$ Lews \& $L$ Taft (Eds ), Developmental disabulities theory, assessment and intervention New York S P Medical \& Scientific Books, in press (b)

Scarr, S Genetic factors in activity motivation Chuld Development, 1966, 37, 663-673

Scarr, S, \& Salapatek, P Patterns of fear development durng infancy Merrill-Palmer Quarterly, 1970, 16, 53-90

Schaffer, $\mathbf{H}$ Activity level as a constitutional determinant of infantule reaction to depnvatuon Child Development, 1966, 37, 595-602

Self, P A Control of infant visual attending by auditory and interspersed stimulation In $\mathbf{F} D$ Horowitz (Ed), Visual attention, auditory stimulation, and language discrimination in young infants Monographs of the Socrety for Research in Chuld Development, 1975, 39/56, Sernal No 158)

Shirley, M M The first two years a study of 25 babies Minneapolis University of Minnesota Press, 1933

Sroufe, L, \& Waters, E The ontogenesis of smling and laughter a perspective on the organzation of development in infancy Psychologecal Review, 1976, 83, 173-189

Thomas, A, \& Chess, S Temperament and development New York Brunner/Mazel, 1977

Thomas, A, Chess, S, \& Birch, H G Temperament and behavior disorders in chuldren New York New York Unuversity Press, 1968

Thomas, A, Chess, S, Birch, H G, Hertzig, M E, \& Korn, S Behavioral individualty in early childhood New York New York Un1versity Press, 1963

Torgersen, A E, \& Knnglen, E Genetuc aspects of temperament differences in infants Joumal of the American Academy of Child Psychuatry, $1978,17,443-449$

Weick, K E Systematic observational methods In G Lindzey \& F Aronson (Eds), Handbook of socral psychology Vol 2. Reading, Mass Addison-Wesley, 1968

Willerman, L Activity level and hyperactivity in twins Child Development, 1973, 44, 288-293

Willerman, L, \& Plomin, $\mathbf{R}$ Activity level in children and their parents Chald Development, $1973,44,854-858$

Wilson, $\mathbf{R}$ S, Brown, A M, \& Matheny, A P, Jr Emergence and persistence of behavioral differences in twins Child Development, 1971, 42, 1381-1398

Yarrow, M R Problems of methods in parentchild research Child Development, 1963, 34, 215-226.

Yerkes, $\mathrm{R}$ M, \& Yerkes, A W Nature and conditions of avoidance (fear) response in the chmpanzees Journal of Comparative Psychology, $1936,21,53-66$ 
This document is a scanned copy of a printed document. No warranty is given about the accuracy of the copy. Users should refer to the original published version of the material. 